\title{
Influence of Die Temperature on Unit Density and Calorific Value of Municipal Solid Waste Pellets
}

\author{
S R H Siregar ${ }^{1}$ D Nursani ${ }^{1}$ A Surjosatyo ${ }^{1, *}$ \\ ${ }^{1}$ Department of Mechanical Engineering, Universitas Indonesia, Kampus Baru UI Depok, 16424, Indonesia. \\ ${ }^{*}$ Corresponding author. Email: adisur@eng.ui.ac.id
}

\begin{abstract}
The process of waste to energy can solve the problem of waste and produce energy as a by-product. The waste can be used as a raw material in pelletization process which then used as a fuel in the thermal processing technology. In the pelletization process there are operational variables that influence the characteristics and quality of the pellets. Variation of waste composition (food waste, garden waste, plastic and paper), die temperature (ambient, $60^{\circ} \mathrm{C}, 80^{\circ} \mathrm{C}, 100^{\circ} \mathrm{C}$, and $150^{\circ} \mathrm{C}$ ) and particle size (mixed, $<0.5 \mathrm{~mm}$, and $0.5-5 \mathrm{~mm}$ ) are done in this study. The waste was processed through natural drying, crushing, and pelletizing using the single pellet press method. The pellet pressure and dimensions of the pellet mold are fixed at $288 \mathrm{MPa}$ and $6 \mathrm{~mm}$ in diameter. Density measured by verniercaliper and precision analytical balance. Calorific value measured by bomb calorimeter PARR 6400. The results showed that there was a simultaneous influence of die temperature on the density and calorific value of the pellet.
\end{abstract}

Keywords: Die Temperature, Pelletization, Municipal Solid Waste, Single Pellet Press

\section{INTRODUCTION}

The process of waste to energy can solve the problem of waste and produce energy as a by-product. Generally, the largest composition of municipal solid waste consist of food waste, garden waste, plastic, and paper, which have a range of combustion heat value up to $30 \mathrm{MJ} / \mathrm{kg}$ [1]. Therefore, the energy contained in municipal solid waste can be processed into alternative fuels.

Based on American Standard Testing and Material (ASTM) definition [2], the utilization of municipal solid waste for production of energy or Refuse Derived Fuel (RDF) classified into 7 type. RDF-1 is waste used as a fuel in as-discarded form. RDF-2 is waste processed to coarse particle size with or without ferrous metal separation. RDF-3 is shredded fuel derived from municipal solid waste that has been processed to remove metal, glass, and other inorganics and has a particle size such that $95 \%$ weight passes through a 2 -inch square mesh screen. RDF-4 is combustible waste processed into powder form with $95 \%$ weight passing a 10 mesh screen. RDF-5 is combustible waste densified (compressed) into the form of pellets, slugs, cubettes or briquettes. RDF-6 is combustible waste processed into liquids fuel. RDF-7 is combustible waste processed into gaseous fuel.

The pelletization process produces pellets which are included in the RDF-5. In this process, there are variables that can affect the properties of the pellets produced which include moisture content of raw material, particle size, presence of binders, and machine parameters such as pressure gap, die diameter, channel length, die speed, etc. [3].

Research related to various of raw materials and specification parameters have been carried out. Demirbas (1999) and Yaman et al. (2000) examined the types of paper waste materials with variable particle size and the addition of organic wheat material [4] and olive pulp [5]. Chiemchaisri et.al., (2010) examined the types of plastic waste materials with the addition of binding agents [6]. Prasityousil et al. (2013), Srivastava et al. (2014) and Ahmad et al. (2018) examined the types of compost waste material [7], vegetable waste [8], and banana plant waste [9]. Nguyen et al. (2015)examined the variations in die temperature parameters, raw material moisture content, operational pressure, and particle size with raw materials of sugar marple wood chips [10]. The same 
research was carried out for each different raw materials, such as Said et al. (2015) with raw materials of straw [11], Ramezanzade et.al., (2018) with raw materials for residual pistachio nuts [12].

Although some researchers investigated various of raw materials and parameter specifications for making pellets, municipal solid waste raw materials especially that is simulated to real conditions have not been carried out. Thus, the main objective of the present study is to investigate influence of die temperature as parameter specification on unit density and calorific values as quality of pellet for municipal solid waste simulated composition based on waste composition collected from Bantargebang landfill which the landfill is dedicated for Jakarta City, Indonesia.

\section{MATERIAL AND METHODS}

\subsection{Sampling}

Samples were taken simultaneously in January 2019. Samples of food waste, plastic, and paper were taken from residential areas while garden waste samples were taken from the yield of sweeping the garden area. The type of food waste is limited by food scraps containing leftover food ingredients such as potato skin, onion skin, fruit peel, fruit stalks, egg shells, corn cobs, and pieces of vegetables that have withered, garden waste only contains a sweep of the Cempedak trees (Artocarpus integer) area at University of Indonesia, plastic waste only contains multilayer plastic pieces, such as snack packages, packaging beverage labels, and candy wrappers, and paper waste only contains pieces of paper bills, shopping receipts, leaflets and brochures.

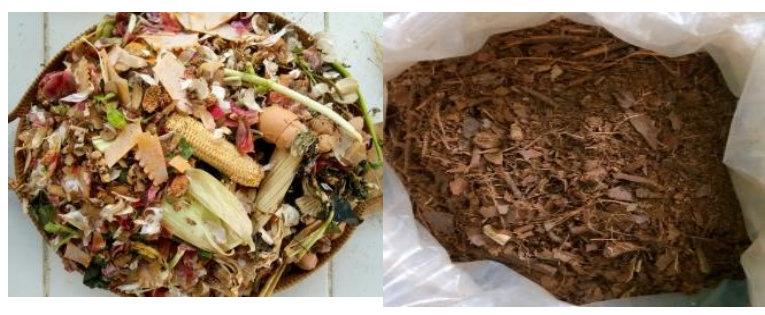

(a)

(b)

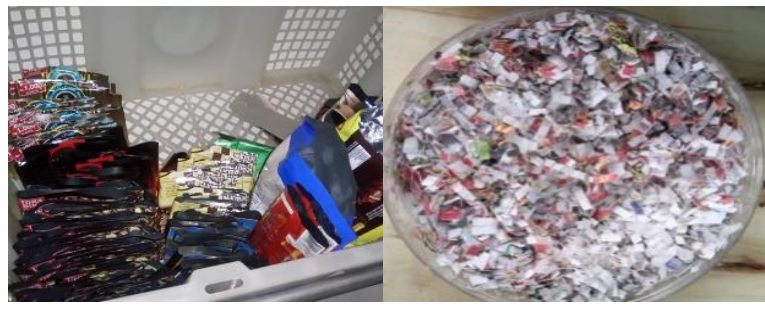

(c)

(d)

Figure 1 Sample material (a) Food Waste, (b) Garden Waste, (c) Plastic, (d)Paper

The composition of waste entering Bantargebang landfill in 2017 consisted of $52.91 \%$ food waste, $6.10 \%$ garden waste, $14.85 \%$ plastic, $7.49 \%$ paper, $3.56 \%$ textile, $1.78 \%$ rubber, $1,94 \%$ metal, $2.60 \%$ glass, $8.76 \%$ others. Furthermore, the sample for this study followes the data from the composition of the landfill, but limited only on the ratio of food waste, garden waste, plastic, and paper. There are two types of composition ratios, namely the ratio of initial conditions (composition A) and alternative conditions. The alternative composition assumed that there is a process of reducing organic waste (food waste and garden waste) with the composting process so that the waste disposed to landfill is reduced by $20 \%$ (composition B).

Table 1. Composition ratio of sample

\begin{tabular}{|l|l|l|}
\hline Composition & Ratio A & Ratio B \\
\hline Food Waste & 70.1 & 66.5 \\
\hline Garden Waste & 8.1 & 7.7 \\
\hline Plastic & 11.9 & 14.1 \\
\hline Paper & 9.9 & 11.8 \\
\hline
\end{tabular}

\subsection{Preparation of Sample}

Sample pre-treatment used the drying and grinding process. Samples were dried naturally (sun drying) for 14 days for food waste and 1-3 days for other wastes. After the raw material was dry enough, the sample was grinded. Grinding was carried out in two stages, where the first stage of grinding for each sample component and the second stage for the combined sample component. The first stage of grinding used an electric blender (food waste and garden waste) and a paper crusher with a maximum yield size of $5 \mathrm{~mm}$ (plastic and paper) while the second stage of grinding used a crusher machine with high speed rotation. The sample milled was sifted with a 30 mesh sieve $(0.5 \mathrm{~mm})$ so that obtained variations in particle size consist of initial size (mixed), <30 mesh $(<0.5 \mathrm{~mm})$ and $>30$ mesh $(0.5-5 \mathrm{~mm})$.

\subsection{Pelletizing Process}

Peletization used a single pellet press method consisting of pellet die and hydraulic press. This method refers to previous studies[3], [10], [13]-[15]. The cylindrical pellet die with a diameter of $6 \mathrm{~mm}$ is made of hardened steel, equipped with a heating element module and calibrated thermocouple. Compression of raw materials was carried out by a hydraulic press at a pressure of $288 \mathrm{MPa}$ for 150 seconds.Die temperature varied from ambient temperature, $60^{\circ} \mathrm{C}, 80^{\circ} \mathrm{C}, 100^{\circ} \mathrm{C}$, and $150^{\circ} \mathrm{C}$.

\subsection{Laboratory Testing}

The pellets that have been produced are then tested in the laboratory to determine the pellet properties. 


\subsubsection{Unit Density.}

Unit density testing is expressed as a ratio of weight per unit volume of pellet units. The testing method refers to previous studies [11], [16], [17]. Density testing is divided into three categories, namely unit density, bulk density, and tapped density. Because of the limited production of pellets, in studies with single pellet press only tested the unit density. Testing equipment includes calipers and analytical scales. Tests were carried out at the Universitas Indonesia Faculty of Engineering Gasification Laboratory and carried out right after the pellet was formed.

\subsubsection{Calorific Value.}

Tests of calorific values are expressed in gross calorific value, namely the amount of heat generated from combustion of a number of fuels at constant volume conditions, in the oxygen bomb calorimeter under specific conditions. The test method for calorific value refers to ASTM E 711-87 about the Standard Test Method for Gross Calorific Value of Refuse Derived Fuel by the Bomb Calorimeter. Tests were carried out at the Analytical Chemistry Laboratory of the Animal Research Center (Balitnak) using bomb calorimeter type PARR 6400 .

\section{RESULTS AND DISCUSSIONS}

\subsection{Pellet Properties}

Table 2 shows the result of the experiments. Pelletizing was held in March 2019 with total number of pellet is 30 pellets consist of 5 variations in die temperature (ambient, $60^{\circ} \mathrm{C}, 80^{\circ} \mathrm{C}, 100^{\circ} \mathrm{C}$, and $150^{\circ} \mathrm{C}$ ), 3 variations in particle size (mixed sizes, sizes $<0.5 \mathrm{~mm}$ and size $0.5-5 \mathrm{~mm}$ ), and 2 variations in waste composition ratio $(\mathrm{A}$ and $\mathrm{B})$

Table 1. Pellet properties result

\begin{tabular}{|c|c|c|c|c|c|}
\hline Exp. No. & Composition & $\begin{array}{l}\text { Particle Size } \\
\text { [mm] }\end{array}$ & Die Temperature $\left[{ }^{\circ} \mathrm{C}\right]$ & $\begin{array}{l}\text { Unit Density } \\
\qquad\left[\mathrm{kg} / \mathrm{m}^{3}\right]\end{array}$ & $\begin{array}{c}\text { Calorific Value } \\
\text { [kcal/kg] }\end{array}$ \\
\hline 1 & A & mixed & 30 & 912 & 3195 \\
\hline 2 & A & $<0.5$ & 30 & 1346 & 1499 \\
\hline 3 & A & $0.5-5$ & 30 & 646 & 4577 \\
\hline 4 & A & mixed & 60 & 785 & 2921 \\
\hline 5 & A & $<0.5$ & 60 & 1370 & 1361 \\
\hline 6 & A & $0.5-5$ & 60 & 810 & 4569 \\
\hline 7 & A & mixed & 80 & 1073 & 3491 \\
\hline 8 & A & $<0.5$ & 80 & 1476 & 1679 \\
\hline 9 & A & $0.5-5$ & 80 & 972 & 4775 \\
\hline 10 & A & mixed & 100 & 1124 & 3180 \\
\hline 11 & A & $<0.5$ & 100 & 1337 & 1982 \\
\hline 12 & A & $0.5-5$ & 100 & 948 & 5093 \\
\hline 13 & A & mixed & 150 & 1227 & 3145 \\
\hline 14 & A & $<0.5$ & 150 & 1457 & 1776 \\
\hline 15 & A & $0.5-5$ & 150 & 987 & 5828 \\
\hline 16 & B & mixed & 30 & 843 & 3009 \\
\hline 17 & B & $<0.5$ & 30 & 1378 & 1844 \\
\hline 18 & B & $0.5-5$ & 30 & 795 & 3916 \\
\hline 19 & B & mixed & 60 & 1014 & 3089 \\
\hline 20 & B & $<0.5$ & 60 & 1470 & 1611 \\
\hline 21 & B & $0.5-5$ & 60 & 936 & 4171 \\
\hline 22 & B & mixed & 80 & 1031 & 2552 \\
\hline 23 & B & $<0.5$ & 80 & 1414 & 2252 \\
\hline 24 & B & $0.5-5$ & 80 & 885 & 4106 \\
\hline 25 & B & mixed & 100 & 1076 & 3806 \\
\hline
\end{tabular}




\begin{tabular}{|l|c|c|c|c|c|}
\hline 26 & B & $<0.5$ & 100 & 1466 & 1408 \\
\hline 27 & B & $0.5-5$ & 100 & 983 & 4445 \\
\hline 28 & B & mixed & 150 & 1158 & 3910 \\
\hline 29 & B & $<0.5$ & 150 & 1488 & 1915 \\
\hline 30 & B & $0.5-5$ & 150 & 950 & 4102 \\
\hline
\end{tabular}

In experiments, ambient temperature shows the die temperature is $30^{\circ} \mathrm{C}$. Unit density of pellet MSW ranging from $646-1.488 \mathrm{~kg} / \mathrm{m} 3$. The smallest unit density is from municipal solid waste with particle size $0,5-5 \mathrm{~mm}$, and the biggest one is from particle size $<0,5 \mathrm{~mm}$. Small particle size can fill more gaps compared to large particle size. This makes the density of smaller particle size has the biggest density value. This condition applies to composition $\mathrm{A}$ and $\mathrm{B}$. The difference in unit density in each composition ratio is not much different.

Calorific value of pellet MSW ranging from 1.361$5.828 \mathrm{kcal} / \mathrm{kg}$. The smallest and the biggest calorific value are from composition $\mathrm{A}$. Where the smallest at die temperature $60^{\circ} \mathrm{C}$ withparticle size $<0,5 \mathrm{~mm}$ and the biggest at die temperature $150^{\circ} \mathrm{C}$ with particle size $0,5-5$ $\mathrm{mm}$.

\subsection{Effect of Die Temperature on Unit Density}

As shown in Figure 2, unit density of the pellets increases with increasing die temperature. However, the increase in unit density values at higher temperatures is getting smaller. This condition shows that there is an optimum die temperature to provide high unit density.

At low die temperature, the protein content in the biomass begins to act as a binding agent [3] even waste paper can be plays the role of a binder [4], [18]. Food waste and garden waste have high protein in the form of lignocellulosic fiber which will increase pellet density. However, at higher temperatures $\left(>130^{\circ} \mathrm{C}\right)$, the presence of lignocellulose fibers reduces the modulus of elasticity of biomass particles and makes them more flexible or softer. This results an empty space between and inside the particles which can reduce pellet density [3]. So that unit density tends to start to decrease.

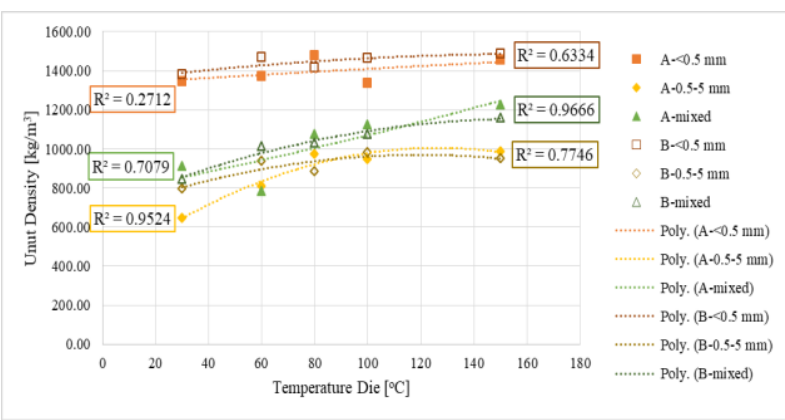

Figure 2 Effect of die temperature on unit density for MSW biomass materials
At particle size $<0.5 \mathrm{~mm}$, unit density does not show a significant change in die temperature. This is because small particle sizes, which contain natural binder, interlocking between particles more stronger than the big particle size. The die temperature does not effect significantly due to the small particles have been fill the gap between particles[13].So that the increase in die temperature does not make a significant change in unit density.

\subsection{Effect of Die Temperature on Calorific Value}

As shown in Figure 3, there are several trends between die temperature and calorific value. The first trend is increasing in composition A particle size 0,5-5 $\mathrm{mm}$ and composition B particle size mixed, the second trend is likely to decrease in composition A particle size mixed and composition $B$ particle size $0,5-5 \mathrm{~mm}$, and the third trend tends to be stable in composition A and B particle size $<0,5 \mathrm{~mm}$.

In the first and second trends the change in trends starts at a temperature range of $80-100 \mathrm{C}$. This is due to an increase in temperature changes in the chemical components of the sample material to form lignocellulose fibers. The amount of lignocellulose will have an impact on the calorific value. In the first trend the amount of material that forms lignocellulose is higher than the second trend. So that the first trend experienced a significant increase in the calorific value.

In the third trend has the lowest calorific value. Due to the minimum chemical component that can be lignocellulose form in both of composition A and B.

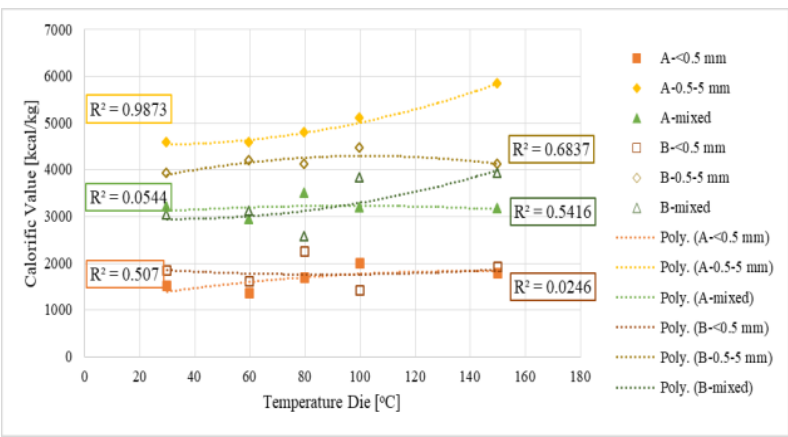

Figure 3 Effect of die temperature on calorific value for MSW biomass materials 


\subsection{Correlation of Unit Density and Calorific Value on MSW Pellets}

Figure 4 shows the correlation between unit density and calorific value based on experimental data. The results show that there are groupings of data at particle size and the same trend for die temperature at each particle size groups.

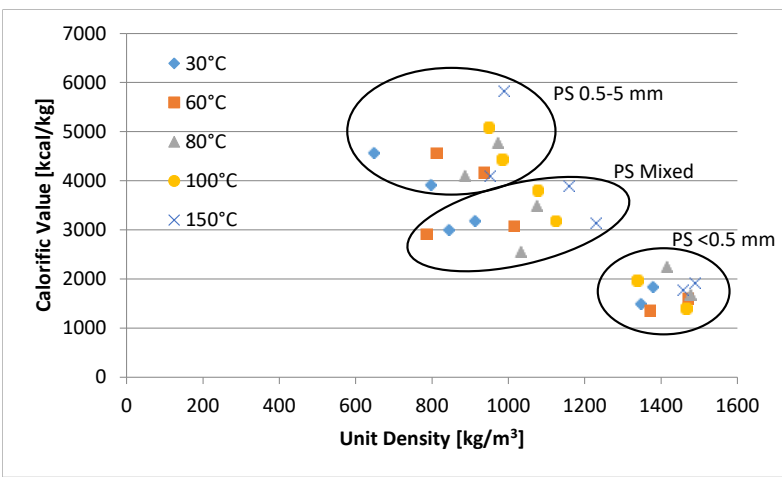

Figure 4 Relation between Pellet Properties (Calorific Value/Unit Density)

The groups with particle size $<0.5 \mathrm{~mm}$ have the highest unit density value but the lowest calorific value and the groups with $0.5-5 \mathrm{~mm}$ particle size have the highest calorific value but the lowest unit density value. The thing that affects these two parameters is the presence of water in the particles of pellet raw material. In the process of pelletization, water evaporation occurs especially at higher temperatures [19]. At low unit density value, more water evaporate through gap between particles so that the calorific value more higher, whereas at high unit density value, water is trapped between particles so that the calorific value becomes lower.

In each particle size group, increasing temperature die results increasing in unit density and calorific value. Difference in increase of unit density value for particle size respectively $<0.5 \mathrm{~mm}$, mixed, and $0.5-5 \mathrm{~mm}$ reached $10.67 \%, 43.18 \%$ and $38.26 \%$ of the average value of the unit density for each group of data. While the difference in the increase in calorific value for particle size in a row $<0.5 \mathrm{~mm}$, mixed, and $0.5-5 \mathrm{~mm}$ reached $51.42 \%$, $42.05 \%$, and $41.95 \%$ of the average calorific value of each group data.

\section{CONCLUSION}

Municipal solid waste can be formed directly into pellets. The die temperature at the time of pelletization process affects the quality of the pellet on the unit density and the calorific value. The higher die temperature results higher calorific value and unit density. Particle size variables also affect the quality of the pellets produced.
It is necessary to develop a methodology or simulation for making large scale municipal solid waste pellets by considering the fluctuations in existing waste. Apart from that the combustion characteristics of the pellets produced will still be further investigated.

\section{ACKNOWLEDGMENTS}

This work is supported by Hibah PITTA B 2019 funded by DRPM Universitas Indonesia No NKB0692/UN2.R3.1/HKP.05.00/2019.

\section{REFERENCES}

[1] N. Sliusar, G. Armisheva, "Energy resources recovery on municipal solid waste disposal," in Sinks a Vital Element of Modern Waste Management: 2nd International Conference on Final Sinks.-2013, 2013.

[2] ASTM International, "ASTM E897-99(2004), Standard Test Method for Volatile Matter in the Analysis Sample of Refuse-Derived Fuel (Withdrawn 2004),"West Conshohocken, PA, 1988.

[3] M. E. Mostafa et al., "The significance of pelletization operating conditions: An analysis of physical and mechanical characteristics as well as energy consumption of biomass pellets," Renewable and Sustainable Energy Reviews, vol. 105. pp. 332 348, 2019.

[4] A. Demirbaş, "Physical properties of briquettes from waste paper and wheat straw mixtures," Energy Conversion and Management, vol. 40, no. 4. pp. 437-445, 1999.

[5] S. Yaman, M. Şahan, H. Haykiri-Açma, K. Şeşen, and S. Küçükbayrak, "Production of fuel briquettes from olive refuse and paper mill waste," Fuel processing technology, vol. 68, no. 1. pp. 23-31, 2000 .

[6] C. Chiemchaisri, B. Charnnok, and C. Visvanathan, "Recovery of plastic wastes from dumpsite as refuse-derived fuel and its utilization in small gasification system," Bioresource Technology, vol. 101, no. 5. pp. 1522-1527, 2010.

[7] J. Prasityousil and A. Muenjina, "Properties of Solid Fuel Briquettes Produced from Rejected Material of Municipal Waste Composting," Procedia Environmental Sciences, vol. 17. pp. 603-610, 2013.

[8] N. S. L. Srivastava, S. L. Narnaware, J. P. Makwana, S. N. Singh, and S. Vahora, "Investigating the energy use of vegetable market waste by briquetting," Renewable Energy, vol. 68. pp. 270 $275,2014$. 
[9] K. Ku Ahmad, K. Sazali, and A. A. Kamarolzaman, "Characterization of fuel briquettes from banana tree waste," Materials Today: Proceedings, vol. 5, no. 10. pp. 21744-21752, 2018.

[10] Q. N. Nguyen, A. Cloutier, A. Achim, and T. Stevanovic, "Effect of process parameters and raw material characteristics on physical and mechanical properties of wood pellets made from sugar maple particles," Biomass and Bioenergy, vol. 80. pp. 338349, 2015.

[11]N. Said, M. M. Abdel Daiem, A. García-Maraver, and M. Zamorano, "Influence of densification parameters on quality properties of rice straw pellets," Fuel Processing Technology, vol. 138. pp. 56-64, 2015.

[12]M. Ramezanzade and A. G. Moghaddam, "Optimizing the production parameters for pellets made from pistachio tree pruning using multiresponse optimization," Waste and biomass valorization, vol. 9, no. 7, pp. 1213-1221, 2018.

[13] Y. Wang, K. Wu, and Y. Sun, "Effects of raw material particle size on the briquetting process of rice straw," Journal of the Energy Institute, vol. 91, no. 1. pp. 153-162, 2018.
[14] Y. Huang et al., "Biofuel pellets made at low moisture content - Influence of water in the binding mechanism of densified biomass," Biomass and Bioenergy, vol. 98. pp. 8-14, 2017.

[15]M. Puig-Arnavat, L. Shang, Z. Sárossy, J. Ahrenfeldt, and U. B. Henriksen, "From a single pellet press to a bench scale pellet mill - Pelletizing six different biomass feedstocks," Fuel Processing Technology, vol. 142. pp. 27-33, 2016.

[16]P. Pradhan, S. M. Mahajani, and A. Arora, "Production and utilization of fuel pellets from biomass: A review," Fuel Processing Technology, vol. 181. pp. 215-232, 2018.

[17] J. S. Tumuluru, "Effect of process variables on the density and durability of the pellets made from high moisture corn stover," Biosystems Engineering, vol. 119. pp. 44-57, 2014.

[18] Y. Li, H. Liu, and O. Zhang, "High-pressure compaction of municipal solid waste to form densified fuel," Fuel Processing Technology, vol. 74, no. 2. pp. 81-91, 2001.

[19] K. Ishii and T. Furuichi, "Influence of moisture content, particle size and forming temperature on productivity and quality of rice straw pellets," Waste Management, vol. 34, no. 12. pp. 2621-2626, 2014. 